\title{
EVALUATION OF THE AGROBIOLOGICAL AND TECHNOLOGICAL POTENTIAL OF SOME VALUABLE HYBRID ELITE OBTAINED AT R.D.S.V.O. ODOBEŞTI
}

\author{
I. Bosoi ${ }^{*}$ and M. Puşcalău ${ }^{1}$ \\ 1Research and Development Station for Viticulture and Oenology Odobești, \\ Ştefan cel Mare street, no. 61, Odobești, Vrancea, Romania \\ *Corresponding author email: oana_boss2002@yahoo.com
}

\begin{abstract}
Over time at Research and Development Stationfor Viticulture and Oenology Odobești, numerous intra- and interspecific sexual hybridizations have been carried out, in order to obtain new cultivars, with high productive and qualitative potential, with disease tolerances, resistant to stress factors, very well adapted to the climatic conditions specific to Vrancea vineyards.Thus, valuable hybrid elites were obtained, which represent a permanent source for the selection, approval and promotion of new grape cultivars. In order to evaluate the agrobiological and technological potential of some valuable hybrid elites, in the period $2016-2018$, two elites were studied: 'E.H. 10-1-6' and 'E.H. 6-1-1'. The results obtained from this study showed that these hybrid elites have a high productive and qualitative potential, show high biological resistance to the main diseases of the vine, and can be proposed for approval in order to improve the national assortment, in the context of sustainable viticulture.
\end{abstract}

Keywords: vines, breeding, resistance, cultivar

\section{INTRODUCTION}

The productivity, quality and adaptability of vine cultivars are very complex characteristics that depend on the genetic traits (inherited genotype or genetic dowry) of each cultivar, environmental conditions and the interaction between genotype and environment (Sestraș, 2004). Research conducted in recent decades in our country, has led to the production of valuable vine genotypes, with high tolerance to disease, drought and frost resistant.The scientific activity of vine improvement was and remains a strategic objective of tradition and continuity at Research and Development Stationfor Viticulture and Oenology Odobeşti (Bosoi et al., 2017, 2018; Puşcalău et al., 2018). In this context, in the last six years, four grape cultivars have been approved, with different production directions: a cultivar for table grapes 'Putna'(2014), a cultivar for superior white wines 'Vrancea'(2018), a cultivar for tinctorial red wines 'Măgura'(2014) and a cultivar for red and rose wines with genetic resistance 'Remus' (2016).

\section{MATERIALS AND METHODS}

The research was performed at the Research and Development Stationfor Viticulture and Oenology (RDSVO) Odobești, between 2016 and 2018. The biological material was represented by two valuable hybrid elites: the hybrid elite 10-1-6 obtained by crossing the 
'Traminer roz' cultivar with the 'Isabella' interspecific hybrid and hybrid elite 6-1-1 obtained by crossing the hybrid combination 'Traminer x Armaş' with the 'Şarba' cultivar. The 'Fetească Regală' cultivar cultivated on large areas in the Odobești, Cotești and Panciu vineyards, was studied as a witness.

The hybrid elites were characterized ampelographic, the phenological spectrum was monitored, were made observation and determinations regarding the elements of fertility and productivity, behavior at the main diseases of the vine, established by assessing with grades from 1 to 9 according to the resistance scale developed by the O.I.V. (2009), quantitative and qualitative potential of grape production.

\section{RESULTS AND DISCUSSIONS}

Ampelograpfic characterizationof the hybrid elite 10-1-6.At disbudding, the rosette is light green, slightly fluffy. The shoot is glabrous and has slightly intense anthocyanin coloration on the sunny side. The adult leaf is medium in size, pentalobate, slightly embossed, glabrous on the upper face and fluffy on the lower face, with the upper lateral sinuses open and the petiolar sinus open in the shape of a lyre. The flower is a normal hermaphrodite, type 5 .

The grapes have a conical shape, rarely cylindrical, are medium to large in size and have medium compactness. The berries are medium-sized, spherical in shape, with pink skin, darker on the sunny side. The pulp does not have anthocyanin coloration, it is juicy, slightly firm, without specific taste (Fig. 1 and Fig. 2).

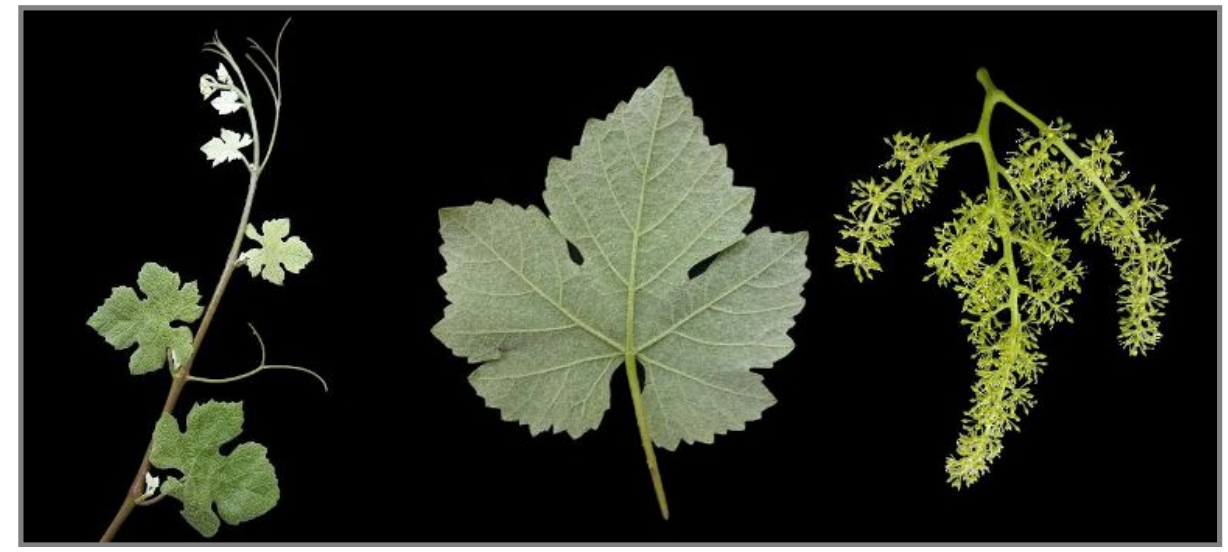

Figure 1. Elite hybrid 10-1-6 (shoot, leaf - lower side, inflorescence)

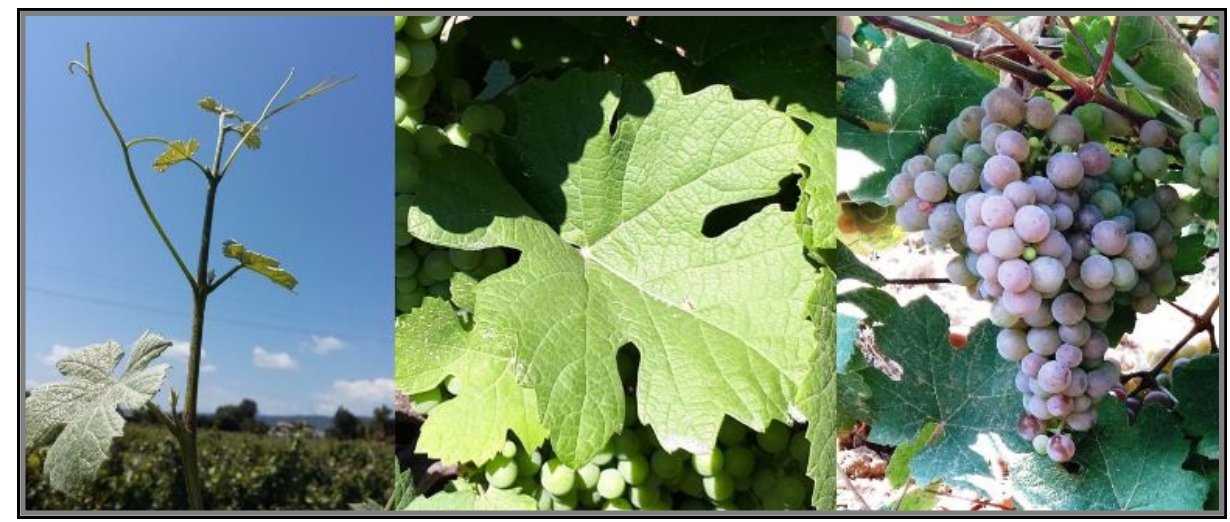

Figure 2. Elite hybrid 10-1-6 (shoot tip, leaf - upper side, grape) 
Ampelograpfic characterization of the hybrid elite 6-1-1.At disbudding, the rosette is light green, slightly fluffy. The shoot is glabrous, with entirely green internodes with longitudinal striations. The adult leaf is small, pentalobate, slightly embossed, glabrous on the upper face. The superior lateral sinuses are deep, with the lobes slightly open, the lower ones open, and the petiolar sinus is semi-open. The flower is hermaphroditic, type 5.

The grapes are small, have a cylindrical shape, very rarely conical, with dense berries. The berries are small, spherical in shape, with golden-yellow skin, with more intense golden hues on the sunny side.The pulp does not have anthocyanin coloration, it is juicy, with a balanced taste, slightly aromatic (Fig. 3 and Fig. 4).

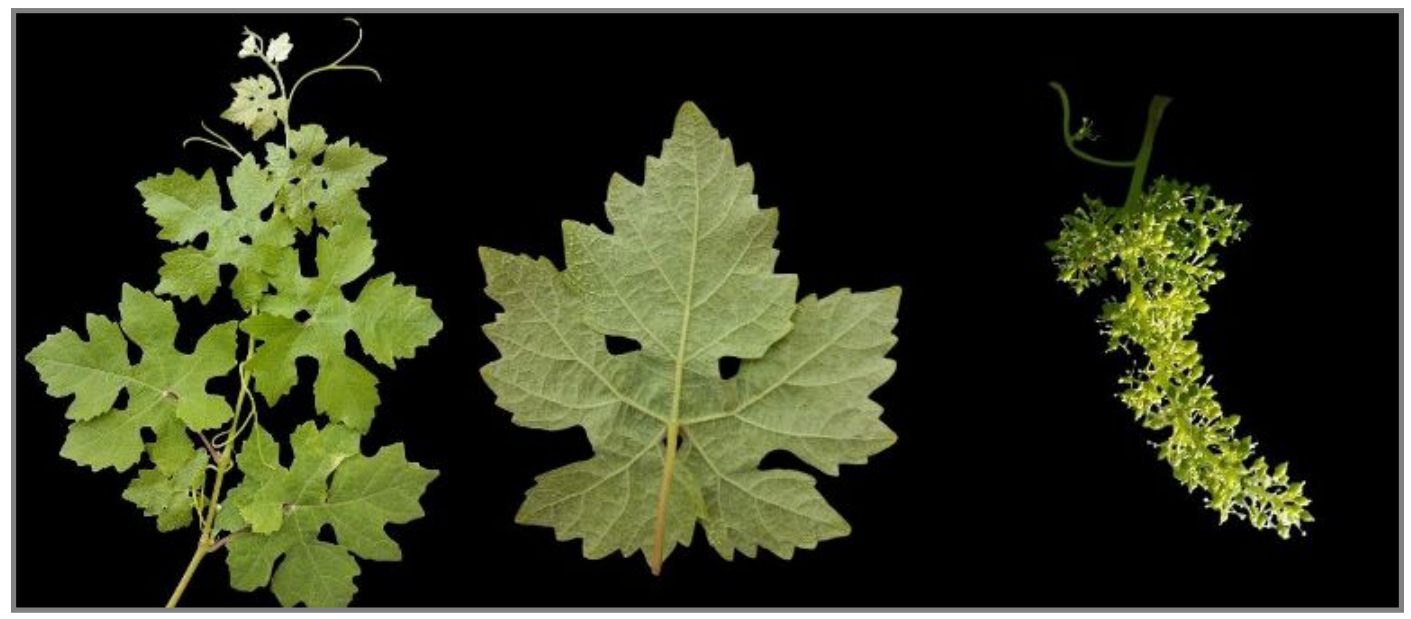

Figure 3. Elite hybrid 6-1-1 (shoot, leaf - lower side, inflorescence)

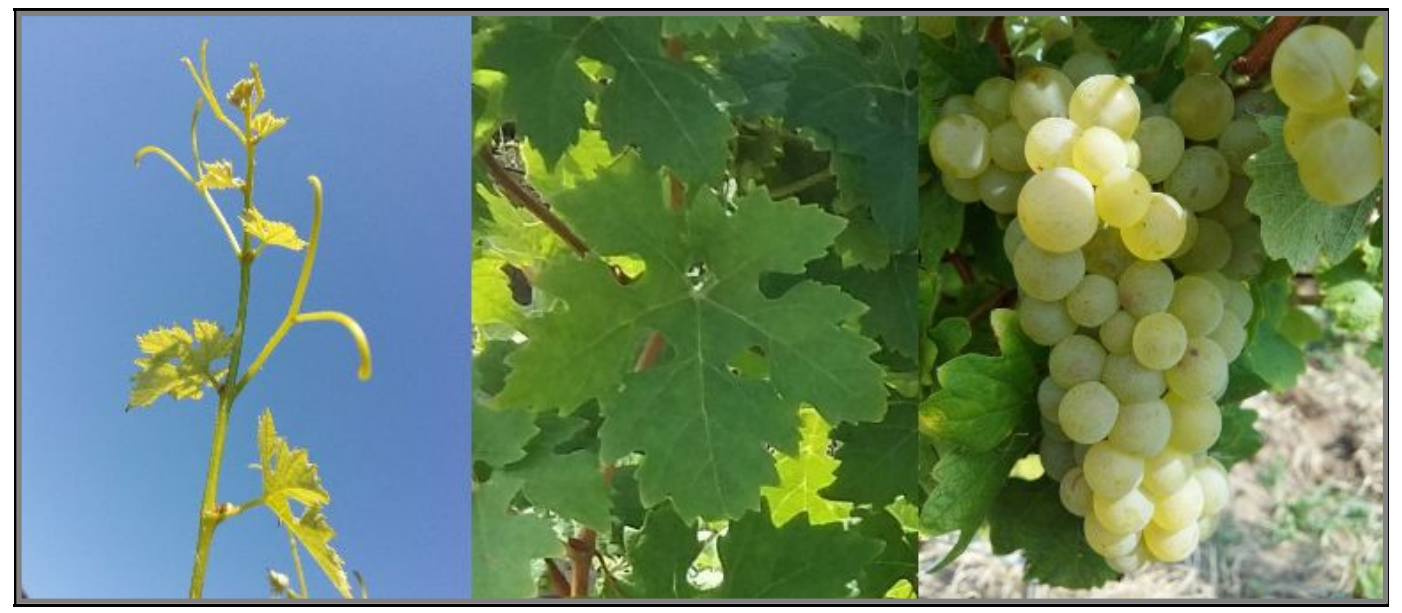

Figure 4. Elite hybrid 6-1-1 (shoot tip, leaf - upper side, grape)

Climatic conditions. The research period (years 2016 - 2018) was characterized by high heliothermal availability, the thermal regime expressed by the average annual temperatures $\left.{ }^{\circ} \mathrm{C}\right)$ and the sum of the useful temperature degrees $\left(\Sigma^{\mathrm{o}} \mathrm{tu}\right)$ registering values much higher than the multiannual ones (Table 1). Compared to the multiannual values $\left(10.5{ }^{\circ} \mathrm{C}\right.$, respectively $1604.1^{\circ} \mathrm{C}$ ), the average annual temperature varied between $12.0{ }^{\circ} \mathrm{C}$ and 13.2 ${ }^{\circ} \mathrm{C}$, and the sum of the useful temperature degrees $\left(\Sigma^{\mathrm{o}} \mathrm{tu}\right)$, between $1933,6^{\circ} \mathrm{C}$ and 2072.8 ${ }^{\circ} \mathrm{C}$. The rainfall regime was a surplus during the vegetation period in all three years of study (between $613.2 \mathrm{~mm}$ and $910.6 \mathrm{~mm}$ ), compared to the multiannual value (431.2 $\mathrm{mm}$ ). 
Table 1. The main climatic parameters from the study period (Odobeşti, 2016-2018)*

\begin{tabular}{|c|c|c|c|c|c|c|c|c|c|c|c|c|}
\hline \multirow{2}{*}{$\begin{array}{l}\text { Climate } \\
\text { parame } \\
\text { ter } \\
\text { / Month }\end{array}$} & \multicolumn{4}{|c|}{ Average temperature $\left({ }^{\circ} \mathrm{C}\right)$} & \multicolumn{4}{|c|}{$\begin{array}{l}\text { The sum of the useful } \\
\text { temperature degrees }\left({ }^{\circ} \mathrm{C}\right)\end{array}$} & \multicolumn{4}{|c|}{ Rainfall (mm) } \\
\hline & $\begin{array}{c}\text { Multi } \\
\text { annual }\end{array}$ & $\begin{array}{c}2015 \\
/ \\
2016\end{array}$ & $\begin{array}{c}2016 \\
/ \\
2017\end{array}$ & $\begin{array}{c}2017 \\
/ \\
2018\end{array}$ & $\begin{array}{l}\text { Multi } \\
\text { annual }\end{array}$ & $\begin{array}{c}2015 \\
/ \\
2016\end{array}$ & $\begin{array}{c}2016 \\
/ \\
2017\end{array}$ & $\begin{array}{c}2017 \\
/ \\
2018\end{array}$ & $\begin{array}{l}\text { Multi } \\
\text { annual }\end{array}$ & $\begin{array}{c}2015 \\
/ \\
2016\end{array}$ & $\begin{array}{c}2016 \\
/ \\
2017\end{array}$ & $\begin{array}{c}2017 \\
/ \\
2018\end{array}$ \\
\hline XI & 5.1 & 9.2 & 5.3 & 6.5 & 9.5 & 45.7 & 5.7 & 1.4 & 45.8 & 108.0 & 68.2 & 70.2 \\
\hline XII & 0.2 & 4.2 & 2.1 & 3.7 & 0.4 & 1.9 & 3.5 & 0.2 & 41.6 & 4.2 & 0.6 & 37.2 \\
\hline $\mathrm{I}$ & -1.6 & -0.9 & -2.8 & 0.2 & 0.1 & 0.0 & 0.0 & 0.0 & 34.3 & 6.4 & 10.2 & 16.6 \\
\hline II & -0.1 & 6.4 & 1.0 & 0.3 & 0.7 & 12.7 & 3.1 & 0.0 & 32.4 & 11.6 & 30.8 & 52.8 \\
\hline III & 4.4 & 8.2 & 9.5 & 2.9 & 12.2 & 18.4 & 28.8 & 3.8 & 32.0 & 52.8 & 24.4 & 29.0 \\
\hline IV & 10.9 & 14.2 & 10.9 & 16.3 & 66.9 & 144.2 & 61.3 & 189.2 & 48.4 & 131.2 & 71.8 & 1.8 \\
\hline $\mathrm{V}$ & 16.4 & 16.7 & 18.2 & 20.4 & 212.8 & 206.3 & 250.3 & 323.6 & $\begin{array}{l}74.3 \\
\end{array}$ & 151.8 & 31.6 & 20.4 \\
\hline VI & 20.0 & 22.7 & 22.4 & 22.5 & 308.9 & 382.6 & 403.0 & 375.5 & 84.1 & 138.4 & 111.4 & 138.6 \\
\hline VII & 22.0 & 24.6 & 22.6 & 22.1 & 371.7 & 452.3 & 391.5 & 374.0 & 78.2 & 13.0 & 93.4 & 181.8 \\
\hline VIII & & & 23.9 & 3.9 & 351.1 & 411.2 & 431.5 & 429.4 & 59.1 & 188.8 & 47.6 & 42.2 \\
\hline IX & 16.7 & 19.6 & 18.9 & 18.2 & 205.4 & 281.4 & 267.7 & 247.8 & 45.0 & 71.4 & 51.8 & 21.0 \\
\hline $\mathrm{X}$ & 10.8 & 9.6 & 12.3 & 14.1 & 64.4 & 34.5 & 87.2 & 127.9 & 42.1 & 216.0 & 84.8 & 1.6 \\
\hline $\begin{array}{c}\text { Annual } \\
\text { average/ } \\
\text { amount }\end{array}$ & 10.5 & 13.2 & 12.0 & 12.6 & 1604.1 & 1991.2 & 33.6 & 2072.8 & 617.3 & 1093.6 & 626.6 & 613.2 \\
\hline $\begin{array}{l}\text { luring the } \\
\text { egetation } \\
\text { period }\end{array}$ & 16.9 & 18.7 & 18.5 & 19.6 & 1581.2 & 1912.5 & 1892.5 & 2067.4 & 431.2 & 910.6 & 492.4 & 407.4 \\
\hline
\end{tabular}

*Data provided by the weather station AgroExpert of R.D.S.V.O. Odobești

The phenological spectrum.The phenology of the hybrid elites studied is presented in Table 2. In the climatic conditions specific to the study period (2016 - 2018) the growth and development processes of the vineevolved normally.

Table 2. The dynamic of the main phenological stages (Odobeşti, 2016 -2018)

\begin{tabular}{|c|c|c|c|c|c|c|c|c|c|c|}
\hline \multirow{3}{*}{$\begin{array}{c}\text { The hybrid } \\
\text { elite }\end{array}$} & \multirow{3}{*}{ Year } & \multicolumn{8}{|c|}{ The phenological stages } & \multirow{3}{*}{$\begin{array}{c}\text { Active } \\
\text { vegetation } \\
\text { period } \\
\text { (days) }\end{array}$} \\
\hline & & \multicolumn{2}{|c|}{ Disbudding } & \multicolumn{2}{|c|}{ Flowering } & \multicolumn{2}{|c|}{ Veraison } & \multicolumn{2}{|c|}{ Full ripening } & \\
\hline & & Date & $\begin{array}{l}\sum \text { tu } \\
\left({ }^{\circ} \mathrm{C}\right) \\
\end{array}$ & Date & $\begin{array}{l}\sum \text { tu } \\
\left({ }^{\circ} \mathrm{C}\right) \\
\end{array}$ & Date & $\sum \operatorname{tu}\left({ }^{\circ} \mathrm{C}\right)$ & Date & $\begin{array}{l}\sum \mathrm{tu} \\
\left({ }^{\circ} \mathrm{C}\right) \\
\end{array}$ & \\
\hline \multirow{3}{*}{ E.H. $10-1-6$} & 2016 & 06.IV & 56.0 & $30 . \mathrm{V}$ & 369.8 & 06.VIII & 1309.1 & 25.IX & 1879.6 & 166 \\
\hline & 2017 & 15.IV & 65.8 & $03 . \mathrm{VI}$ & 367.9 & $10 \mathrm{VIII}$ & 1306.4 & 18.IX & 1777.4 & 157 \\
\hline & 2018 & 17.IV & 84.9 & $23 . \mathrm{V}$ & 410.0 & 03.VIII & 1307.2 & 10.IX & 1807.9 & 147 \\
\hline Average & & 13.IV & 68.9 & $29 . \mathrm{V}$ & 382,6 & 06.VIII & 1307.6 & 18.IX & 1821.6 & 157 \\
\hline \multirow{3}{*}{ E.H. 6-1-1 } & 2016 & 06.IV & 56.0 & $30 . \mathrm{V}$ & 369.8 & 01.VIII & 1234.4 & 03.IX & 1662.2 & 151 \\
\hline & 2017 & 13.IV & 57.9 & $01 . \mathrm{VI}$ & 360.6 & 03.VIII & 1193.1 & $08 . I X$ & 1655.1 & 148 \\
\hline & 2018 & 15.IV & 71.8 & $21 \mathrm{~V}$ & 389.2 & 21.VII & 1143.7 & 01.IX & 1709.7 & 140 \\
\hline Average & & 11.IV & 61.9 & 27.V & 373.2 & 28.VII & 1190.4 & 04.IX & 1675.7 & 146 \\
\hline \multirow{3}{*}{$\begin{array}{l}\text { Fetească } \\
\text { Regală } \\
\text { (Control) }\end{array}$} & 2016 & 09.IV & 76.2 & $30 . \mathrm{V}$ & 369.8 & 04.VIII & 1277.3 & 06.IX & 1699.9 & 151 \\
\hline & 2017 & 14.IV & 61.3 & $01 . \mathrm{VI}$ & 360.6 & 03.VIII & 1193.1 & 14.IX & 1725.7 & 154 \\
\hline & 2018 & 16.IV & 75.3 & $20 . \mathrm{V}$ & 379.5 & 22.VII & 1155.6 & 04.IX & 1752.6 & 142 \\
\hline Average & & 13.IV & 70.9 & $27 . V$ & 370.0 & 30.VIII & 1208.7 & 08.IX & 1726.1 & 149 \\
\hline
\end{tabular}

The full ripening of the grapes took place at the hybrid elite 10-1-6 between September 18 and 25, with four to 10 days later compared to the control cultivar, and in the first decade of the September at the hybrid elite 6-1-1, about a week earlier than the 'Fetească Regală' cultivar (Control).

Fertility and productivity characteristics.The fertility and productivity characteristics of the hybrid elites studied, assessed by the percentage of fertile shoots, fertility coefficients 
(absolute and relative) and productivity indices (absolute and relative) show lower values compared to the control. In contrast, due to the higher average weight of the grapes, the hybrid elite 10-1-6 showed values of productivity indices higher than the control cultivar (Table 3).

Table 3. The fertility and productivity characteristics (Odobeşti, average data 2016-2018)

\begin{tabular}{|c|c|c|c|c|c|c|}
\hline \multirow{2}{*}{ The hybrid elite } & \multirow{2}{*}{$\begin{array}{c}\text { Fertile } \\
\text { shoots } \\
(\%)\end{array}$} & \multicolumn{2}{|c|}{ Fertility coefficients } & \multirow{2}{*}{$\begin{array}{c}\text { Average } \\
\text { weight } \\
\text { grapes (g) }\end{array}$} & \multicolumn{2}{|c|}{ Productivity indices } \\
\hline & & Relative & Absolute & & Relative & Absolute \\
\hline E.H. 6-1-1 & 64 & 0,68 & 1,08 & 134 & 95 & 151 \\
\hline E.H. 10-1-6 & 62 & 0,78 & 1,20 & 267 & 208 & 320 \\
\hline $\begin{array}{c}\text { Fetească Regală } \\
\text { (Control) }\end{array}$ & 75 & 1,02 & 1,31 & 138 & 141 & 181 \\
\hline
\end{tabular}

Behavior at the main diseases of the vine.The biological resistance to the main cryptogamic diseases of the vine appreciated according to the descriptors OIV 452, 453, 455 456, 458 şi 459 is presented in the table 4.

Table 4. The behavior at the main diseases of the vine

\begin{tabular}{|l|c|c|c|c|c|c|}
\hline \multirow{2}{*}{ The hybrid elite } & \multicolumn{2}{|c|}{$\begin{array}{c}\text { Downy mildew } \\
\text { (Plasmopara viticola) }\end{array}$} & \multicolumn{2}{c|}{$\begin{array}{c}\text { Powdery mildew } \\
\text { (Uncinula necator) }\end{array}$} & \multicolumn{2}{c|}{$\begin{array}{c}\text { Gray rot } \\
\text { (Botrytis cinerea) }\end{array}$} \\
\cline { 2 - 7 } & $\begin{array}{c}\text { Leaf } \\
\text { OIV 452 }\end{array}$ & $\begin{array}{c}\text { Grape } \\
\text { OIV 453 }\end{array}$ & $\begin{array}{c}\text { Leaf } \\
\text { OIV 455 }\end{array}$ & $\begin{array}{c}\text { Grape OIV } \\
456\end{array}$ & $\begin{array}{c}\text { Leaf } \\
\text { OIV 458 }\end{array}$ & $\begin{array}{c}\text { Grape OIV } \\
459\end{array}$ \\
\hline E.H. 6-1-1 & 7 & $7-9$ & 7 & $7-9$ & $7-9$ & 5 \\
\hline E.H. 10-1-6 & 7 & 9 & 7 & $7-9$ & $7-9$ & $5-7$ \\
\hline $\begin{array}{c}\text { Fetească Regală } \\
\text { (Control) }\end{array}$ & 7 & 7 & 7 & 7 & 7 & 5 \\
\hline
\end{tabular}

The obtained data show that during the study period (2016-2018), years that registered during the vegetation period favorable climatic conditions for the attack of cryptogamic diseases, under the application of the scheme of anticryptogamic treatments, the hybrid elites studied showed high resistance, superior to the control cultivar - Fetească Regală. The elite hybrid6/1/10 stood out by high biological resistance to the three main diseases of the vine.

Technological characteristics of grape production.The study of the technological characteristics of grape production complemented the knowledge elements for the hybrid elites studied (Table 5). The number of grapes per vine and the obtained production confirm the fertility data for the two hybrid elites compared to the control. The hybrid elite 10-1-6 was noted with a production of $5.87 \mathrm{~kg} / \mathrm{vine}$, superior to the control cultivar ( $4.14 \mathrm{~kg} / \mathrm{vine})$.

Table 5. The quantitative and qualitative characteristics of grapes and juice

(average data, Odobeşti, 2016-2018)

\begin{tabular}{|c|c|c|c|c|c|c|c|}
\hline \multirow[b]{2}{*}{ The hybrid elite } & \multirow{2}{*}{$\begin{array}{c}\text { No. } \\
\text { bunch/ } \\
\text { vine }\end{array}$} & \multirow{2}{*}{$\begin{array}{c}\text { Weight } \\
\text { grapes } \\
\text { (g) }\end{array}$} & \multirow{2}{*}{$\begin{array}{c}\text { Weight } \\
100 \text { berry } \\
\text { (g) }\end{array}$} & \multicolumn{2}{|c|}{ Production grape } & \multicolumn{2}{|c|}{ The juice } \\
\hline & & & & $\mathrm{kg} /$ vine & $\mathrm{kg} / \mathrm{ha}$ & $\begin{array}{c}\text { Sugars } \\
\text { g/l }\end{array}$ & $\begin{array}{l}\text { Total acidity } \\
\mathrm{g} / 1 \mathrm{H}_{2} \mathrm{SO}_{4}\end{array}$ \\
\hline E.H. 6-1-1 & 24 & 135 & 136 & 3.22 & 12.197 & 236 & 3.12 \\
\hline E.H. 10-1-6 & 22 & 267 & 202 & 5.87 & 22.235 & 217 & 4.74 \\
\hline $\begin{array}{l}\text { Fetească Regală } \\
\text { (Control) }\end{array}$ & 30 & 138 & 139 & 4.14 & 15.682 & 191 & 4.16 \\
\hline
\end{tabular}

From a qualitative point of view, the hybrid elites studied were above the control cultivar, with higher values of sugar content in must (236 g/l for 'E.H. 10-1-6' and $217 \mathrm{~g} / \mathrm{l}$ for 'EH 6-1- 
1', respectively $191 \mathrm{~g} / \mathrm{l}$ for the 'Fetească Regală' cultivar). A good value of the total acidity relative to the sugar content was achieved by the hybrid elite 10-1-6 (4.74 g/ $\left.\mathrm{l} \mathrm{H}_{2} \mathrm{SO}_{4}\right)$. Lower total acidity was recorded by the hybrid elite 6-1-1 (3.12 g/ $\left.\mathrm{H}_{2} \mathrm{SO}_{4}\right)$, under conditions of high sugar accumulation.

\section{CONCLUSIONS}

- $\quad$ The two hybrid elites studied at R.D.S.V.O. Odobeşti during the years 2016 - 2018, presented valuable agrobiological and agro-productive characteristics which recommends their proposal for homologation and promotion in culture for the diversification of the local assortment of cultivars with high ecological plasticity.

- $\quad$ The hybrid elite 10-1-6 was distinguished by a high productive and qualitative potential, as well as a good genetic resistance to the main diseases of the vine (downy mildew, powdery mildew and gray rot).

- $\quad$ The hybrid elite 6-1-1 stood out with good results regarding the qualitative and productive potential, as well as by a high tolerance to the main cryptogamic diseases.

\section{ACKNOWLEDGEMENTS}

This study was carried out in 2015-2018 within the ADER project 3.2.5./2015 Diversification of the wine cultivar for table grapes and wine, ADER 2020 Sector Plan, funded by the Ministry of Agriculture and Rural Development (MARD).

\section{REFERENCES}

1. Bosoi Marioara, Mihu Ghică, Bosoi Ionica, (2017) - Măgura - new cultivar of vine for red wines created at S.C.D.V.V. Odobeşti, Lucrări ştinţifice USAMV Iaşi, Seria Horticultură, Anul LIX - vol 60(1), , 57-63.

2. Bosoi Ionica, Puşcalău Marioara, (2018) - Vrancea - soi nou pentru obţinerea vinurilor albe de calitate superioară creat la S.C.D.V.V. Odobești, Revista HORTUS, nr.,16/2018, 281 -286.;

3. OIV descriptor list for grape cultivars and Vitis species, 2nd edition - 2009

4. Puşcalău Marioara, (2018) - Remus - new cultivar of vine for rose and red wines with high biological resistance, Lucrări știinţifice UŞAMV Iaşi, Seria Horticultură, 61(1), 129-135..

5. Sestraş R. (2004). - Improvement of horticultural species, Cluj-Napoca, RO: Ed. 